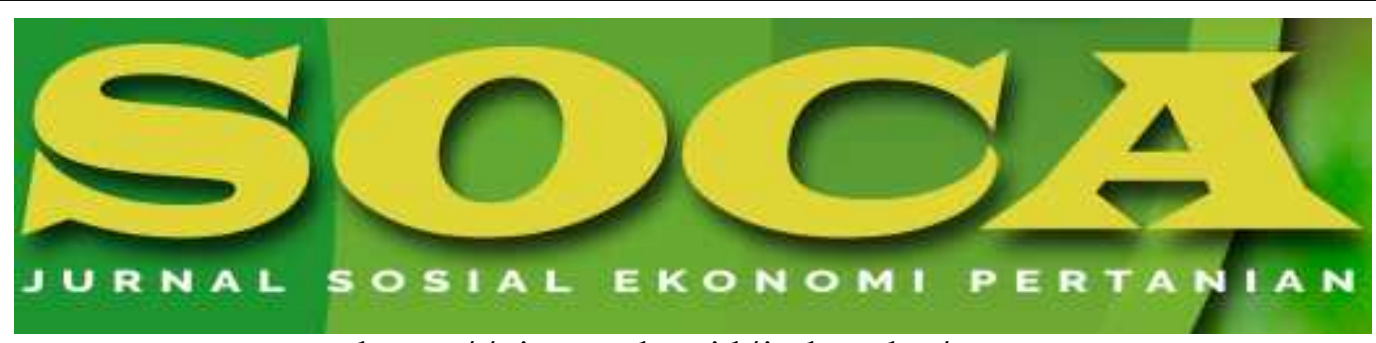

https://ojs.unud.ac.id/index.php/soca

\title{
KEBANGKITAN LADANG BERPINDAH DI NAGARI SILAYANG KECAMATAN MAPATTUNGGUL SELATAN KABUPATEN PASAMAN PROVINSI SUMATERA BARAT
}

\author{
Juli Yusran, Yonariza, Elfindri dan Mahdi \\ Universitas Andalas, Padang, Provinsi Sumatera Barat \\ Emailkorespondensi: yusranj@ymail.com,yonariza@hotmail.com,elfindribana@gmail.com, \\ kuteihmahdi@yahoo.com \\ Telp. 081267306034, 08126769298, 08126600296, 085272625091
}

\begin{tabular}{l} 
Kata Kunci: \\
ladang \\
berpindah, \\
harga, \\
pendapatan, \\
edukasi \\
lingkungan \\
\hline
\end{tabular}

Kata Kunci:

ladang

berpindah,

harga,

edukasi

lingkungan

\begin{abstract}
Abstrak
Pembangunan infrastruktur dan ProRLK (Proyek Rehabilitas Lahan Kritis) proyek kerja sama Pemerintah dengan GTZ (The German Technical Coorperation Agency) tahun 1992, menggeser ladang berpindah ke pertanian karet di Nagari Silayang. Petani yang berladang berpindah untuk kebutuhan pangan, menghentikan praktek yang membudaya ini, dan berfokus pada perkebunan karet untuk memenuhi pangan dan uang kes. Tapi beberapa tahun belakangan, praktek ladang berpindah kembali marak di Nagari Silayang. Fenomena ini membantah teori transformasi pertanian dalam banyak penelitian sebelumnya, yang menyimpulkan bahwa pergeseran pola pertanian mengarah pada pola yang semakin meninggalkan ladang berpindah. Tujuan penelitian adalah menemukan faktor-faktor yang menyebabkan rumah tangga petani di Nagari Silayang kembali berladang berpindah, dan menemukan cara atau strategi untuk menghentikan pembukaan hutan untuk lahan perladangan. Penelitian menggunakan metode gabungan kualitatif dan kuantitatif. Data dikumpulkan melalui observasi, wawancara key informan serta survey rumah tangga. Hasil penelitian menunjukkan bahwa kebangkitan ladang berpindah di Nagari Silayang, disebabkan oleh penurunan harga karet global, menjaga keamanan pangan, dan upaya peningkatan pendapatan rumah tangga. Ini akan berdampak pada kerusakan keragaman hayati dan bahkan bencana alam, karena hutan tua dikonversi menjadi lahan pertanian. Diperlukan strategi untuk mengurangi dan/ atau
\end{abstract}


menghentikan praktek ladang berpindah dengan cara meningkatkan nilai produksi karet petani, menciptakan sumber pendapatan selain budidaya tanaman yang dapat menyita curahan tenaga kerja rumah tangga petani dan edukasi lingkungan.

\section{REVIVAL OF SHIFTING CULTIVATION IN NAGARI SILAYANG, MAPATTUNGGUL SUBDISTRICT, PASAMAN REGENCY, WEST SUMATRA PROVINCE}

\begin{tabular}{l}
\hline Keywords: \\
shifting \\
cultivation, \\
price, income, \\
environmental \\
education \\
\hline
\end{tabular}

\begin{abstract}
Abstrak
Infrastructure development and ProRLK (deforested Land Rehabilitation Project) a Government of Indonesia collaboration prpject with The German Technical Coorperation Agency (GTZ) in 1992, has shifted the pattern of shifting cultivation to rubber farming in Nagari Silayang. Households engaged in shifting cultivation for food needs, stopped this entrenched practice, and focused on rubber plantations for food needs and financial means. But in recent years, the practice of shifting cultivation has been rife in Nagari Silayang. This phenomenon refutes the theory of agricultural transformastion in many previous studies, which concluded that shifting agricultural patterns lead to patterns that increasingly leave shifting cultivation. The purpose of this study, is to find the factors that cause farm households in Nagari Silayang to return to shifting cultivation, and find ways or strategies to stop forest clearing for swidden land. The research method used is descriptive qualitative and quantitative. Data collection uses observation, key informant interviews and household surveys. the results showed that the revival of shifting cultivation in Nagari Silayang was caused by the decline in global rubber prices, maintaining food security, and efforts to increase household income. This will have an impact on biodiversity damage and even natural disasters, because old forests are converted to agricultural land. This leads to negative impacts on biodiversity and can result in natural disasters, as old forests are converted to agricultural land.
\end{abstract}

How to Cite (APA 6th Style):

Yusran, J., Yonariza, Elfindri, \& Mahdi. (2020). Kebangkitan Ladang Berpindah Di Nagari Silayang Kecamatan Mapattunggul Selatan Kabupaten Pasaman Provinsi Sumatera Barat. SOCA: Jurnal Sosial Ekonomi Pertanian, 14(1), 1-13. https://doi.org/https://doi.org/10.24843/SOCA.2020.v14.i01.p01

\section{PENDAHULUAN}

Perladangan berpindah adalah sistem pertanian yang secara budaya telah menjadi dasar dari penggunaan lahan, mata pencaharian dan tradisi di daerah dataran tinggi selama berabad-abad (Merts et al., 2009, Vliet el al., 2012, Dressler et al., 2015, Mukul, 2016). Namun beberapa decade yang lalu, transformasi pertanian mengarah pada pola pertanian yang semakin meninggalkan ladang berpindah. Proses pergeseran sistem budidaya ladang berpindah, dipicu oleh 
pertumbuhan penduduk, perubahan permintaan pasar, dan kebijakan publik utamanya sejak tahun 1970-an (Merts et al., 2009; Mulyoutami; 2010, Padoch, 2010; Vongvisouk, 2014). Pergeseran pola ladang berpindah tersebut juga disebakan oleh kondisi lingkungan dan kesejahteraan masyarakat, yang mempengaruhi akses dan sistem penguasaan lahan (Contreras, dkk, 2006; Michon, dkk, 2005). Perladangan berpindah trodisional mengalami proses intensifikasi, misalnya dengan menanam tanaman komersial permanen di lokasi lahan ladang berpindah (Raintree \& Warner, 1986). Teegalapalli and Datta (2016) mengklaim bahwa perladangan berpindah tidak lagi relevan, jika dilihat dari populasi dan pertumbuhannya.

Menurut Yonariza (1996), pergeseran pola ladang berpindah ke pertanian menetap di Nagari Silayang, disebabkan oleh beberapa alasan antara lain; menurunnya produksi padi gogo karena masa bera dipersingkat, peningkatan lahan sawah irigasi, kebijakan harga beras pemerintah, meningkatnya produksi dataran rendah karena intensifikasi yang membuat harga beras di pasar mengalami penurunan nilai dan relatif stabil. Di sisi lain harga komoditas ekspor, seperti karet mengalami peningkatan nilai sehingga lebih menarik daripada berladang berpindah untuk produksi beras.

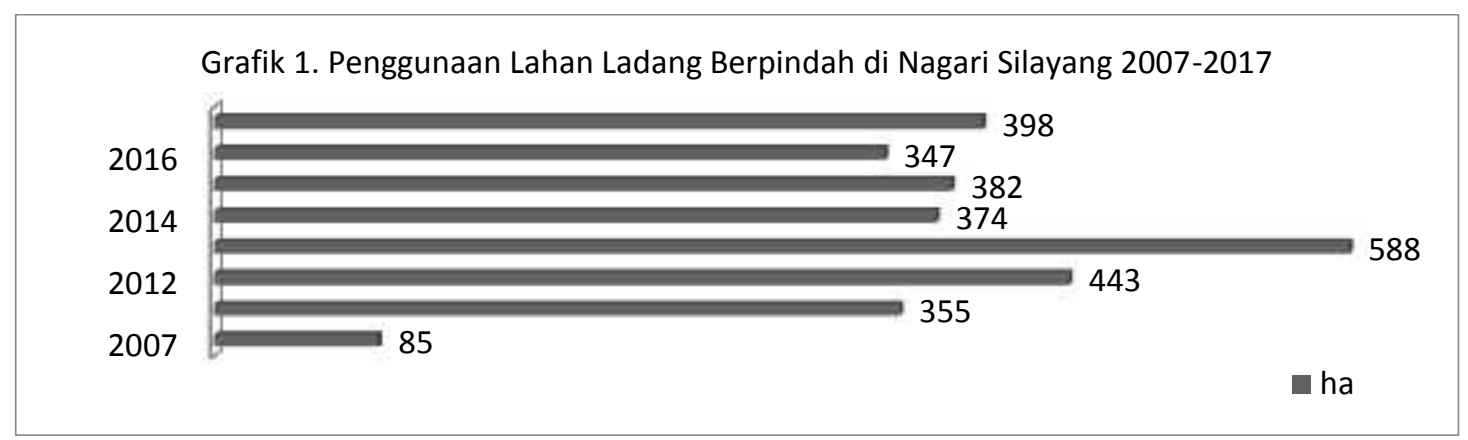

Gambar 1. Penggunaan Lahan Ladang Berpindah di Nagari Silayang 2007-2017 Sumber: BPS, Pasaman dalam Angka (data diolah).

Tapi beberapa tahun belakangan ini, ladang berpindah kembali marak di Nagari Silayang. Kebangkitan kembali ladang berpindah di Nagari Silayang menurut Mahdi dan Yonariza (2017) dipicu oleh turunnya harga karet. Harga karet dunia turun 275 sen AS pada 2011 menjadi 0,55 dolar AS pada 2016 per kg, sedangkan harga beras stabil di Rp 15.000(US $\$ 1,5)$ per kg. Ini berarti, pendapatan petani menurun tajam dan mengganggu mata pencaharian petani yang telah mengubah tanah mereka dari sistem perladangan berpindah menjadi perkebunan karet.

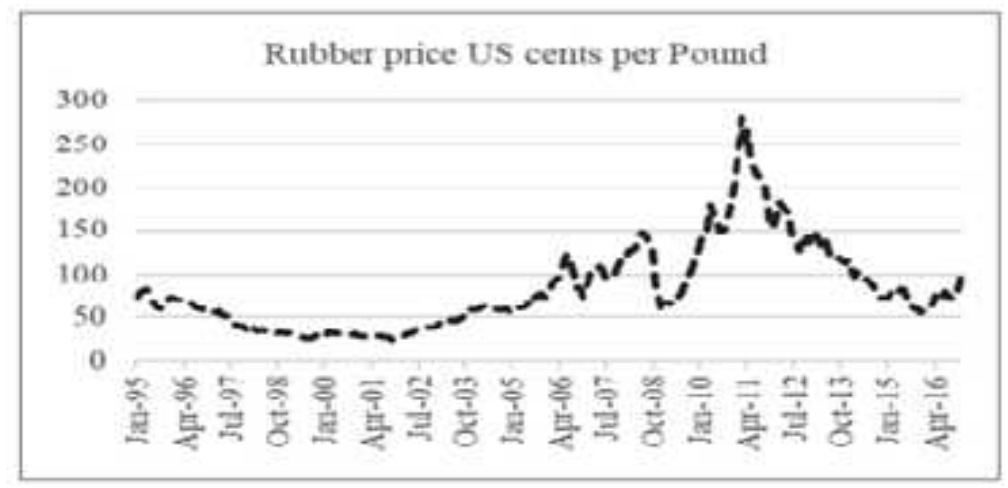

Gambar 2. Fluktuasi Harga Karet Dunia 1995-2016 Sumber: Mahdi dan Yonariza, 2017 
Tulisan ini melanjutkan penelitian Mahdi, Yonariza (2017), yang mengkonfirmasi keputusan rumah tangga petani kembali mempraktekkan pola ladang berpindah karena pengaruh pasar. Sehingga, strategi yang dapat dilakukan untuk menghentikan ladang berpindah adalah dengan subsidi harga melalui skema asuransi harga, jika harga karet lebih rendah dari Rp 8000. Menurut hemat penulis, perkembangan tingkat kebutuhan dan pengaruh luar di Nagari Silayang saat ini, asuransi harga belum cukup untuk menghentikan praktek pola ladang berpindah. Diperlukan strategi lain, selain asuransi harga, agar petani benar-benar menghentikan praktek ladang berpindah tersebut.

\section{METODE PENELITIAN}

Jenis penelitian ini bersifat gabungan kualitatif dan kuantitatif. Gambaran fakta atau karakteristik responden didapatkan melalui pengumpulan data dan informasi di lokasi penelitian. Kumpulan data tersebut kemudian disusun dan dianalisis sehingga dapat menjelaskan faktor-faktor rumah tangga petani karet di Nagari Silayang, kembali mempraktekkan pola ladang berpindah. Penelitian dilaksanakan di Nagari Silayang, karena di daerah ini ditemukan gejala peralihan pola pertanian dari perkebunan karet ke pola ladang berpindah kembali. Kegiatan riset dilaksanakan dalam kurun waktu \pm 3 bulan, Juni - September 2019. Sampel penelitian terdiri dari sampel area dan sampel responden. Sampel area diambil tiga perkampungan yang paling banyak berladang berpindah kembali di Nagari Silayang yaitu; Mentundak, Kampung Padang dan Kampung Baru. Selanjutnya sampel responden diambil dari rumah tangga petani karet yang beralih menjadi peladang berpindah secara purposive. Karena jumlah populasi masih sulit diketahui secara pasti, maka metode penarikan sampel yang digunakan adalah non probability sampling. Jumlah responden keseluruhan sebanyak 60 rumah tangga. Pengambilan sampel responden 60 rumah tangga merujuk pada Bailay (1999), standar sampel minimum jika menggunakan analisis data statistik adalah 30 dan menyebar normal. Penentuan sampel area dilakukan dengan purposive sampling dengan tujuan menentukan perkampungan yang mayoritas petaninya melakukan alih usahatani dari perkebunan karet ke ladang berpindah. Dari total 15 perkampungan di Nagari Silayang diambil tiga perkampungan berdasarkan karakteristik penelitian yaitu; Kampung Mentundak, Kampung Padang dan Kampung Baru. Data primer didapatkan dari hasil observasi, wawancara dan kuesioner. Sedangkan, data sekunder merupakan data dari lembaga-lembaga pemerintah, literatur dan publikasi hasil penelitian sebelumnya yang relevan.

Untuk melihat faktor-faktor yang mempengaruhi petani karet beralih ke pola ladang berpindah dilakukan dengan model analisis regresi logistic yang menghasilkan persamaan dengan variabel dependen bersifat kategorikal. Kategori model akan menghasilkan binary values angka o dan 1, mewakili kategori tertentu dari perhitungan probabilitas kategori tersebut dengan rumus (Gujarati, 1991):

Keterangan:

$$
1 n \frac{P}{1-P}=\alpha+\beta \mathrm{X}
$$

$\mathrm{Pi}=$ angka probabilitas pilihan petani

$\alpha=$ Konstanta

$\beta=$ Parameter yang dicari

$\mathrm{Xi}=$ Variabel yang mempengaruhi

Sedangkan rumus model keputusan biner adalah:

Keterangan:

$$
\mathrm{Yi}=\alpha+\beta_{1} \mathrm{X}_{1}+\beta_{2} \mathrm{X}_{2}+\beta_{3} \mathrm{X}_{3}+\beta_{4} \mathrm{X}_{4}+\beta_{5} \mathrm{X}_{5}+\mathrm{e}
$$

Yi = Variabel keputusan berladang berpindah kembali, dimana Yi $=1$ jika petani alih usahatani dan $\mathrm{Yi}=0$, petani jika tidak alih usaha tani.

$\mathrm{a}=$ Konstanta 
$\mathrm{X}_{1}=$ luas lahan karet (ha)

$\mathrm{X}_{2}=$ curahan tenaga kerja terhadap pekerjaan selain budidaya karet

$\mathrm{X}_{3}=$ harga karet

$\mathrm{X}_{4}=$ Pendapatan

$\beta_{1-} \beta_{5}=$ koefisien regresi

$\mathrm{e}=$ random error

Hipotesis:

$\mathrm{H}_{\mathrm{o}}: \beta_{1}=\beta_{1}=\ldots . .=\beta_{\mathrm{i}}=0$, jika variabel independen tidak berpengaruh terhadap keputusan beralih ke ladang berpindah.

$\mathrm{H}_{\mathrm{a}}$ : paling kurang satu $\left(\beta_{\mathrm{i}} \neq 0\right)$, jika variabel independen berpengaruh terhadap praktek berladang pindah kembali. LR diperbandingkan dengan tabel Chi Square $\left(\mathrm{X}^{2}\right)$. Jika tabel Chi Square < LR hitung berarti $\mathrm{H}_{0}$ ditolak. Ini berarti, secara bersamasama variabel independen berpengaruh terhadap variabel dependen.

\section{HASIL DAN PEMBAHASAN}

\section{Karakteristik Responden.}

Menurut Isdijoso (1990), aspek-aspek yang mempengaruhi keterampilan petani dalam mengelola usahataninya adalah; usia, pendidikan, jumlah tanggungan dan pengalaman berusaha tani. Usia petani berkaitan dengan pengaruh terhadap kemampuan kerja. Sebab, biasanya petani usia muda dan sehat dapat berkerja lebih kuat dan energik, cepat menerima inovasi dan kurang takut terhadap resiko. Semakin menua usia petani, maka semakin berkurang pulalah semangat kerja. Hanya saja, biasanya pengaman hidup membuat mereka lebih berhati-hati dan unggul dalam pengambilan keputusan pengelolaan usahataninya.

Tabel 1. Umur Petani Responden di Nagari Silayang

\begin{tabular}{llccc}
\hline No & Nama Kampung & Umur (Tahun) & $\begin{array}{c}\text { Jml } \\
\text { Responden }\end{array}$ & $\begin{array}{c}\text { Persentase } \\
\text { (\%) }\end{array}$ \\
\hline 1 & Kampung Mentundak & $>39$ & 9 & 45 \\
& & $40-51$ & 6 & 30 \\
2 & \multirow{2}{*}{ Kampung Padang } & $51-62$ & 5 & 25 \\
& & $>39$ & 7 & 45 \\
& & $40-51$ & 9 & 30 \\
3 & \multirow{2}{*}{ Kampung Baru } & $51-62$ & 4 & 25 \\
& & $>39$ & 8 & 45 \\
& & $40-51$ & 6 & 25 \\
\hline
\end{tabular}

Sumber: Data Primer (diolah), 2019

Kinerja seseorang dapat ditentukan oleh usianya (Suratiyah, 2006). Bertambahnya umur dan pekerjaan fisik yang berat mengakibatkan kemampuan bekerja menurun. Tabel di atas menjelaskan bahwa petani karet dan peladang berpindah yang menjadi responden, pada umumnya berumur produktif. Maka, Pengelolaan pertaniannya, masih berpotensi dapat meningkatkan produktivitasnya. Jika dilihat dari tingkat pendidikan petani di Nagari Silayang relatif bervariasi mulai dari tidak menamatkan pendidikan SD sampai pada Strata 1 (S1). Pendidikan mayoritas petani responden adalah SLTP sebanyak 28 orang (46.67\%), disusul SLTA sebanyak $36.37 \%$. Sisanya $16.98 \%$ berada pada tingkat pendidikan tidak tamat $\mathrm{SD}$, tamat SD, diploma dan $\mathrm{S} 1$.

Faktor lain yang dapat mempengaruhi usahatani adalah jumlah tanggungan keluarga. Satu sisi, tanggungan keluarga dapat berkontribusi terhadap ketersediaan tenaga kerja, namun disi lain, jumlah tanggungan keluarga berkonsekuensi terhadap beban ekonomi keluarga. Jumlah tanggungan keluarga responden 
mayoritas sebanyak 4-6 orang yaitu 39 rumah tangga atau 65\%, memiliki tanggungan sebanyak 1 sampai 3 orang, sebanyak 17 orang (28\%). Sisanya sebanyak 4 rumah tangga atau 7 persen memiliki jumlah tanggungan selainnya. Sedangkan pengalaman bertani dan umur petani sangat berkaitan dengan tingkat keahliannya. Pada umumnya, responden sudah berpengalaman dalam bertani selama 3-30 tahun. Sebagian kecil, yaitu 4 rumah tangga berpengalaman bertani kurang dari 3 tahun atau lebih 30 tahun.

\section{Kondisi Usahatani Karet di Nagari Silyang}

Nagari Silayang adalah satu dari 37 nagari di Kabupaten Pasaman. Nagari merupakan nama lain dari desa, sebagai bentuk pemerintahan terendah di Sumatera Barat. Nagari bersifat otonom dan kekuasaan sosial - politik lain, tidak dapat mengintervensi persoalan adat di sebuah nagari. Nagari yang satu dengan nagari lainnya sangat dimungkinkan berbeda-beda. Lembaga perwakilan dari pimpinan suku-suku nagari, biasa disebut KAN (Kerpatan Adat Nagari). Menurut Elfindri (2010: 47), Semua keputusan dan peraturan nagari, harus terlebih dahulu melalui musyawarah dan mufakat dengan KAN. Secara administratif, pemerintahan nagari berada pada level di bawah kecamatan dalam Kabupaten. Sedangkan dalam struktur pemerintahan kota, bukan nagari melainkan kelurahan. Jika dibandingkan dengan kelurahan, maka nagari diberi hak dan kewenagan untuk mengatur wilayahnya secara lebih luas.

Anggota KAN berasal dari tungku tigo sajarangan yang terdiri dari utusan; alim ulama, cerdik pandai (intelektual) dan niniak mamak (pemimpin suku-suku dalam nagari). Bamus Nagari terdiri dari unsur KAN, bundo kanduang, pemuda dan perwakilan tiap suku. Priodesasi masa jabatan Bamus adalah 6 tahun dan hanya dapat dipilih maksimal 2 priode masa jabatan. Anggota Bamus minimal lima orang dan maksimal 11 orang, disesuaikan dengan luas geografis, banyak penduduk, dan kesanggupan keuangan nagari, ditetapkan dengan keputusan Bupati.

Penerapan sistem pemerintahan nagari di Provinsi Sumatra Barat, secara otomatis diiukuti oleh kewenangan atas penguasaan tanah ulayat nagari dan tanahtanah adat baik yang dimiliki secara individual maupun telah dikuasai negara sebelumnya.

Luas lahan petani. Usaha perkebunan karet di Nagari Silayang pada umumnya ladang berawal dari tanah ulayat (komunal) yang sebelumnya dijadikan lahan ladang berpindah. Lahan yang sebelumnya ditanami padi, kemudian ditanami karet atas izin dari pemegang tanah ulayat yang bergelar Datuak Bosar. Perubahan sistem pertanian dari ladang berpindah ke pertanian karet juga berpengaruh terhadap penguasaan lahan di Nagari Silayang, dari sebelumnya berstatus milik "kaum" ke penguasaan atau penggunaan yang lebih privat. Hanya saja status lahan tetap sebagai hak guna atau pemanfaatan lahan yang tidak boleh diperjual belikan, kecuali kepada sesama cucu kemanakan pemegang hak ulayat.

Luas lahan karet petani di Nagari Silayang bervariasi, tergantung luas ladang berpindah yang pernah digarap. Luas lahan budidaya karet garapan responden untuk usahatani karet di Nagari Silayang berada diantara 0,5 - 3 hektar. Mayoritas responden memiliki perkebunan karet seluas 0,5-1 hektar sebanyak 35 rumah tangga (58 persen), disusul $>1-2$ hektar sebanyak 20 orang (33 persen), dan sisanya sebanyak 5 rumah tangga ( 8 persen), memiliki luas lahan $>2-3$ ha. Sedangkan rerata-rata luas lahan karet responden adalah 1,15 persen. Sedangkan luas lahan rata-rata ladang berpindah responden adalah 1,3 ha dengan rincian, lahan di bawah 1 ha berjumlah 18 rumah tangga (30\%), $1-2$ ha berjumlah 40 rumah tangga $(67 \%)$, dan sisanya (2 rumah tangga) memiliki luas lahan ladang berpindah di atas 2 ha/ musim. Lahan ladang berpindah tersebut sebagian besar berasal dari pembukaan hutan tua, dan sebagian kecil lahan perkebunan karet. 


\section{Curahan Tenaga Kerja Petani kepada Usaha Lain Selain Bertani}

Secara umum, pengelolaan usaha tani di Nagari Silayang hanya mengandalkan tenaga kerja rumah tangga sendiri. Di samping bertani, sebagian kecil petani responden memiliki pekerjaan lain selain bertani, seperti berdagang, tenaga honor di kantor camat, kantor wali nagari dan guru. Kondisi ini mempengaruhi jam kerja bertani karena sebagian waktu tersita pekerjaan lain.

Tabel 4. Jenis Pekerjaan lain Selain Berkebun Karet Responden

\begin{tabular}{lccccc}
\hline \multirow{2}{*}{ Sampel Area } & \multicolumn{4}{c}{ Jenis Pekerjaan Lain } & \multirow{3}{*}{ Jonorer } \\
\cline { 2 - 5 } & \multirow{2}{*}{ Pedagang } & K. Camat & K. Nagari & Guru & \\
\cline { 2 - 5 } & 2 & 0 & 1 & 1 & 5 \\
\hline Kampung Mentundak & 1 & 0 & 1 & 1 & 3 \\
Kampung Padang & 2 & 1 & 0 & 0 & 2 \\
Kampung Baru & $\mathbf{5}$ & $\mathbf{1}$ & $\mathbf{2}$ & $\mathbf{2}$ & $\mathbf{1 0}$ \\
Jumlah & & &
\end{tabular}

Sumber: Survey, 2019

Dari total 60 responden terdapat $10(16,7 \%)$, rumah tangga memiliki jenis pekerjaan selain bertani, yaitu; 4 rumah tangga berdagang, 2 orang guru honorer, dan hononer di kantor camat di satu rumah tangga, dan 2 rumah tangga di Kantor Wali Nagari.

Produksi Usahatani Responden. Produksi karet responden di Nagari Silayang cukup bervariasi. Hal ini disebabkan oleh beragamnya luas kebun petani. Jika dirata-ratakan, produksi karet responden adalah $253 \mathrm{~kg} / 1.15 /$ bulan. Sedangkan rerata produksi usahatani ladang berpindah sebesar 3.5 ton GKP/ 1.3 ha/ permusim. Jika dikonversi ke beras menjadi sekitar $2.135 \mathrm{~kg} / 1.3 \mathrm{ha}$.

Analisis Pendapatan Petani. Besar-kecilnya pendapatan petani tergantung pada beberapa faktor antara lain; penggunaan faktor produksi, luas lahan, produksi, harga, dan efesiensi tenaga kerja. Menurut Soekartawi (1993), harga dan produksi adalah sumber ketidak pastian. Pendapatan petani akan berubah, jika harga produksi mengalami perubahan. Pendapatan kotor responden dari karet dengan produksi rata-rata $253 \mathrm{~kg}$ dengan kondisi harga sekarang Rp 6500,- per kg, adalah $253 \mathrm{~kg}$ x Rp 6.500 x $12=19.974 .000 /$ tahun, setara Rp 1.664.500/bulan. Pendapatan bersih rata-rata petani dari hasil karet setelah dikurangi biaya produksi Rp 1.664.500 - Rp 1,383.600 = Rp 280.900,- / bulan.

Penerimaan kotor ladang berpindah responden rata-rata adalah $2.135 \mathrm{~kg} \mathrm{x}$ $\mathrm{Rp} 10.000=\mathrm{Rp} 21.350 .000$ per tahun atau sebesar 1.779 .1667 per bulan. Sedangkan pendapatan rumah tangga petani ladang berpindah setelah dikeluarkan biaya produksi adalah Rp 1.779.1667-1.260.000 = Rp 529.667/1.3 ha/ bulan. Secara ekonomi, penghasilan petani berbanding lurus dengan harga jual, produksi dan penggunaan faktor produksi. Jadi dengan harga karet Rp 6.500,00/ kg, dengan rata-rata luas lahan karet 1.15 ha dan 1.30 ha ladang berpindah, maka pendapatan rumah tangga petani yang berladang berpindah lebih besar dari karet.

\section{Analisis Faktor-Faktor Yang Mempengaruhi Petani Kembali Berladang Berpindah}

Regresi logistic membentuk variabel predictor atau respon $(\log (\mathrm{p} /(1-\mathrm{p}))$, adalah gabungan linear independen variabel. Analisis ini digunakan untuk mengetahui pengaruh variabel independen terhadap variabel dependen, dimana variabel $\mathrm{Y}$ adalah dummy keputusan petani terikatnya adalah 0 , jika petani tidak beralih ke pola ladang berpindah dan 1 jika petani karet beralih ke pola ladang berpindah, dengan memasukkan variabel faktor-faktor yang mempengaruhi keputusan petani. Koefesien estimasi variabel independen yang signifikan menyebabkan beralih usahatani ke ladang berpindah ada 2 dari 4 variabel yang diuji 
yaitu; harga karet dan pendapatan. Sedangkan 2 variabel lain, luas lahan dan curahan tenaga kerja terhadap perkerjaan lain tidak berpengaruh terhadap alih usahatani ke perladangan berpindah.

Hasil analisis regresi logistic menghasilkan nilai adjusted $R$-squared $=0,6421$ menandakan bahwa variasi dari pilihan petani beralih komoditi dan tetap (Y) mampu dijelaskan secara serentak oleh luas lahan $\left(\mathrm{X}_{1}\right)$, harga karet $\left(\mathrm{X}_{3}\right)$ dan pendapatan $\left(\mathrm{X}_{4}\right)$ sebesar $63,10 \%$, sedangkan sisanya sebesar 36,90\% dijelaskan oleh faktor lain yang tidak masuk dalam model. Sedangkan hasil uji F-statistik signifikan sebesar 21,32731 dengan kesalahan (alpa 5\%), maka $\mathrm{H}_{0}$ diterima karena nilai uji $\mathrm{F}>$ alpa $5 \%$.

Uji t-statistik digunakan untuk menguji pengaruh variabel-variabel bebas terhadap variabel tak bebas secara parsial. Uji t-statistik menyimpulkan, bahwa hanya variabel harga karet $\left(\mathrm{X}_{3}\right)$ dan pendapatan $\left(\mathrm{X}_{4}\right)$ yang dapat mempengaruhi keputusan petani beralih ke ladang berpindah kembali. Penjelasan masing-masing variabel independen terhadap pilihan beralih ke ladang berpindah adalah sebagai berikut:

a. Luas Lahan dan Pekerjaan Lain Petani Responden

Luas lahan petani karet bervariasi dari $<1$ ha s/d 3 ha. Rerata luas lahan karet 1.15 ha dan rerata luas ladang berpindah adalah 1.30 ha. Sebanyak 16,7 \% responden, memiliki pekerjaan lain selain bertani karet. Luas lahan berpengaruh negatif terhadap probalititas pilihan responden beralih ke ladang berpindah dengan nilai koefesien -0,0892. Artinya, semakin luas karet petani maka kemungkinan petani beralih ke ladang berpindah semakin kecil.

b. Curahan Tenaga Kerja Petani terhadap Pekerjaan Lain

Curahan tenaga kerja terhadap pekerjaan selain bertani berpengaruh negative terhadap alih usahatani dengan nilai $-0,0042$, artinya curahan tenaga kerja responden terhadap perkerjaan lain tidak berpengaruh terhadap beralihnya petani ke ladang berpindah. Sebab, bertani di Nagari Silayang hanya mengandalkan tenaga kerja rumah tangga sendiri. Penggunaan curahan tenaga kerja ke sektor tertentu, secara otomatis mengurangi waktu kerja untuk pembukaan ladang berpindah. Tidak terdapat perbedaan tanda koefesien yang diharapkan (expected sign) pada peluang tidak terjadinya alih usahatani.

c. Harga Karet

Variabel harga karet signifikan terhadap probalitas peralihan ke ladang berpindah dengan koefesien 8,36. Penurunan harga karet mempengaruhi keputusan petani berladang pindah kembali. Peluang alih komoditi terhadap harga karet dengan angka 2.68, menunjukkan bahwa peluang petani karet beralih ke ladang berpindah karena besarnya selisih harga antara $1 \mathrm{~kg}$ karet dengan harga 1 $\mathrm{kg}$ beras adalah 2,68 kali. Semakin tinggi selisih harga karet dengan beras maka semakin besar peluang beralih ke ladang berpindah. 
Tabel 1. Jumlah Peladang Berpindah, Rerata Harga Karet dan Beras di Nagari Silayang

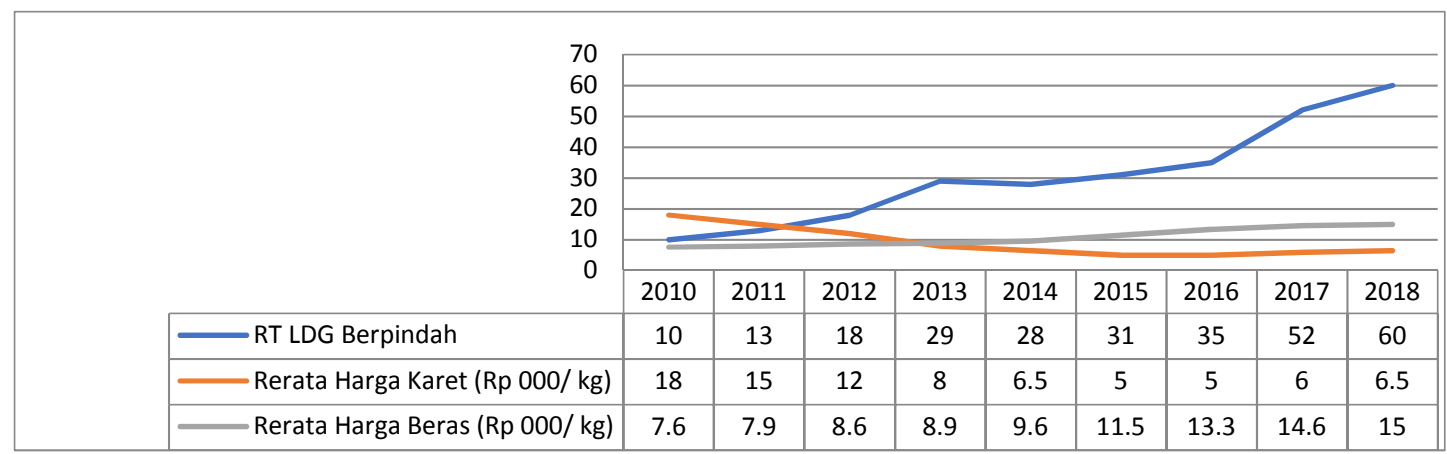

Sumber: Responden, 2019 (data diolah)

Harga karet di tingkat petani turun drastis dari Rp 18.000 - 20.000 pada tahun 2011, menjadi Rp 5000 per kg sejak 2014 dan naik ke 6.500 pada tahun 2018. Sedangkan informasi dari petani, masyarakat Nagari Silayang akan berhenti berladang berpindah, jika harga karet di atas Rp 8000/ $\mathrm{kg}$ (US\$ 0,62). Rumah Tangga Petani meyakini bahwa dengan harga karet di atas Rp 8000 / kg, cukup untuk memenuhi kebutuhan pangan dan uang tunai untuk keperluan lain (Mahdi dan Yonariza, 2017).

d. Pendapatan

Rumah Tangga Petani akan terus melakukan suatu kegiatan jika kegiatan tersebut dianggap dapat memberikan pendapatan yang sesuai (Azmi, 2008). Penelitian ini mengkonfirmasi, tingkat pendapatan yang diperoleh petani menjadi salah satu faktor utama alasan pilihan keputusan petani karet beralih ke pola ladang berpindah. Variabel pendapatan signifikan dengan koefesien sebesar 1,15 bermakna pendapatan yang diperoleh petani berpeluang mempengaruhi keputusan petani beralih ke pola ladang berpindah. Setiap pengurangan pendapatan sebesar satu juta rupiah, menambah probabilitas petani beralih sebesar 11,5 persen. Rendahnya pendapatan dan hasil produksi pertanian dikarenakan berdasarkan kondisi eksisting rata-rata pendapatan kotor di sektor perkebunan karet. Luas rerata $1,15 \mathrm{ha} /$ rumah tangga petani dengan harga $\mathrm{Rp} 6.500,-$ / $\mathrm{kg}$, setelah dikeluarkan biaya produksi hanya sebesar Rp 280.900/bulan. Sedangkan pendapatan bersih rumah tangga petani ladang berpindah, setelah ongkos produksi dikeluarkan sebesar Rp 529.667/1.3 ha/ bulan. Selain padi, ladang berpindah juga menghasilkan tanaman sayuran, cabe, tomat, mentimun, dan umbi-umbian. Sebab itu, meskipun hasil ladang berpindah juga tidak besar, tapi membuat petani merasa lebih aman dalam ketersediaan pangan.

Praktek ladang berpindah di Nagari Silayang juga secara budaya adalah cara untuk mendapatkan akses terhadap tanah komunal dan media transisi menuju tanaman komersial yang diyakini lebih dapat meningkatkan pendapatan rumah tangga. Dari informasi yang diperoleh dari responden, pohon karet yang mereka miliki, dahulunya bekas ladang berpindah. Setelah pohon karet mereka besar dan dirasa cukup untuk memenuhi kebutuhan rumah tangga termasuk pangan, mereka menghentikan kegiatan ladang berpindah dan fokus mengurus perkebunan. Tapi ketika harga karet anjlok dan berlangsung cukup lama, mereka kembali berbodongbondong membuka hutan tua untuk dijadikan ladang berpindah. Jika alih usaha karet ke ladang berpindah tidak terkendali, akan menyebabkan terjadinya bencana alam seperti banjir dan erosi dimusim hujan dan kekeringan dimusim kemarau. 


\section{Ladang berpindah Sebagai Strategi Pemenuhan Kebutuhan Hidup Nagari Silayang}

Berdasarkan uraian sebelumnya, dan terkonfirmasi pada saat wawancara dengan responden, beralihnya petani dari karet ke ladang berpindah kembali adalah strategi untuk bertahan hidup dan upaya meningkatkan pendapatan. Pilihan pola ini antara lain dilatar belakangi oleh pengalaman bertani masyarakat Nagari Silayang, yang dahulunya pernah lama mempraktekkan ladang berpindah. Pergeseran ini juga diperkuat oleh akses tradisi budaya, yang menjadikan pola ladang berpindah sebagai cara akses terhadap lahan. Karena, warga boleh menggarap tanah ulayat untuk pembukaan ladang berpindah, dan memanfaatkannya untuk tanaman pertanian lainnya pasca panen, dengan syarat tidak diperjual belikan kepada orang luar dan yang berbeda suku (kaum).

Cara petani Nagari Silayang dalam menyikapi turunnya nilai produksi karet ini, relatif unik jika dibandingkan dengan nagari atau daerah lain. Di nagari TarungTarung Kecamatan Rao Kabupaten Pasaman misalnya, petani karet menyikapinya dengan menjual karet murni (tanpa campuran), karena dengan karet murni tersebut mereka mendapatkan hasil jual tertinggi. Untuk mengantisipasi kekurangan pendapatan dari karet jika musim hujan atau karena harga karet rendah, mereka menambah sumber penghasilan dari budidaya ikan kolam, bersawah dan berdagang. Belum ditemukan petani yang menjual hasil karetnya langsung kepada pabrik (Rianto, 2014). Di Desa Toman Sumatera Selatan, untuk menjaga fluktuasi harga, petani karet mensiasatinya dengan tanaman sela gambir melalui modifikasi jarak tanam. Petani karet menerapkan pola jarak ganda untuk memperpanjang tanaman sela gambir (Nugraha, dkk: 2018). Sedangkan faktor-faktor yang mempengaruhi pendapatan petani karet di Nagari Limo Koto Kecamatan Koto VII Kabupaten Sijunjung adalah luas lahan dan jumlah produksi (Weriantoni, dkk, 2017).

Dampak dari pergeseran pola perkebunan karet ke ladang berpindah, akan memperpanjang dampak kerusakan lingkungan di Nagari Silayang. Kondisi ini memprihatinkan, sehingga perlu upaya praktis untuk menghentikan praktek ladang berpindah, apalagi pembukaan hutan baru untuk ditanami padi dan tanaman pertanian lainnya.

\section{Upaya Penanggulangan Ladang Berpindah}

Upaya penanggulangan ladang berpindah di Nagari Silayang dapat dilakukan dengan dua pendekatan. Pertama, peningkatan nilai tambah karet, dengan cara menjaga standar mutu, menjual hasil karet petani langsung ke pabrik dan atau hilirisasi pengolahan karet rumah tangga di lokasi yang mudah diakses oleh petani karet Nagari Silayang. Kedua, menciptakan sumber-sumber pendapatan baru selain budidaya tanaman yang dapat menyita waktu rumah tangga petani, sehinga petani tidak punya cukup waktu lagi mencurahkan tenaga kerja untuk membuka lahan baru untuk ladang berpindah.

Informasi yang diterima dari key informan (toke karet), pada umumnya karet dari Nagari Silayang masuk pada kategori tidak murni di tingkat pabrik dengan kadar dan jenis campuran yang bervariasi. Sehingga harga karet mereka di pabrik, tidak pernah mencapai harga maksimal. Pada hal, menjaga standar mutu produksi karet ditingkat petani sangat menentukan harga ditingkat pabrik pengolahan karet. Berdasarkan data wawancara dengan Pak Budi (Kepala Laboratorium pabrik pengolahan karet Famili Raya) di Padang, pada saat harga ditingkat petani Rp $6.500,00$,- berdasarkan harga pasar global ditingkat pabrik mencapai Rp 16.500, dengan catatan kadar air $0 \%$ dan mutu tanpa campuran. Jika terkait kadar air tidak terlalu mempengaruhi harga, karena hanya bersifat pengurangan berat sesuai bobot air. Tapi, jika sifatnya campuran material lain, langsung membuat harga menjadi anjlok, karena pabrik mesti mengeluarkan atau membersihkan bahan 
campuran tersebut dari karet. Upaya ini tentu membutuhkan biaya operasional tinggi, dan dibebankan kepada petani. Dengan demikian, menyesuaikan standar mutu dengan pabrik pengolahan dan memangkas rantai pasar, sebenarnya sudah dapat meningkatkan nilai produksi yang dihasilkan petani secara signifikan. Demikian pula dengan inisiasi industri setengah jadi di daerah yang masih mudah dijangkau oleh petani karet Nagari Silayang.

Alternatif kedua adalah, menciptakan sumber pendapatan baru yang tidak rentan dengan fluktuasi harga global. Mengurangi ketergantungan petani dari pasar global, akan mengeleminir kasus yang sama dengan kasus harga karet. Komoditi pertanian alternatif yang dikembangkan sedapat mungkin tidak hanya memposisikan petani sebagai penerima harga (price taker), tapi pada komoditas yang memperkuat petani sebagai pembuat harga (price maker). Strategi ini juga akan memperkuat nilai tawar dan kemandirian petani.

Strategi mengurangi dampak pasar global dan memperkuat peran petani dalam menentukan harga di Nagari Silayang adalah dengan cara mengidentifikasi peluang pasar lokal dan regional yang masih terbuka, berdasarkan potensi penguasaan teknologi sumber daya petani dan kecocokan dengan potensi Sumberdaya Alam. Dan, peluang itu masih sangat terbuka disektor peternakan, apalagi jika dikaitkan dengan masih sangat kurangnya pasokan daging, telor dan unggas untuk memenuhi kebutuhan pasar di Kabupaten Pasaman. Berdasarkan informasi dari Kepala Bidang Dinas Peternakan dan Kesehatan Hewan pada Dinas Pertanian Kabupaten Pasaman, Pasaman masih sangat kekurangan pasokan daging ayam dan telur, sehingga masih memasok dari Payakumbuh. Begitu juga dengan kambing dan sapi, terutama pada saat hari raya kurban. Maka, menjadikan Nagari Silayang sebagai sentral peternakan, unggas, kambing dan sapi di Kabupaten Pasaman, disamping akan menciptakan sumber penghasilan baru, juga akan menjadikan petani semakin dinamis dalam berfikir dan mempersempit waktu luang mereka untuk membuka lahan baru ladang berpindah. Jika dikelola dengan baik, kotoran ternaik juga akan bermanfaat untuk pupuk organik tanaman pertanian mereka, sehingga mengurangi biaya produksi budidaya.

\section{KESIMPULAN DAN SARAN}

\section{Kesimpulan}

Penyebab dari maraknya kemali praktek ladang berpindah di Nagari Silayang adalah penurunan harga karet dan pendapatan petani. Pilihan petani karet kembali berladang berpindah, terjadi pada petani yang memiliki luas kebun karet di bawah 3 ha dan tidak memiliki sumber pendapatan lain selain hasil karet. Oleh sebab itu, kata kunci dalam upaya mengurangi atau menghentikan kembali praktek ladang berpindah di Nagari Silayang adalah meningkatkan sumber pendapatan dan curahan tenaga kerja rumah tangga petani kepada pekerjaan selain budidaya tanaman.

\section{Saran}

Peningkatan pendapatan dari karet dapat dilakukan dengan menjaga standar mutu karet petani, menjual hasil karet langsung ke pabrik dan/ atau mendirikan pabrik mini pengolahan karet di lokasi yang mudah diakses. Stategi lain, menciptakan sumber-sumber pendapatan lain selain budidaya tanaman seperti; peternakan dan perikanan. Kegiatan ini dapat dibarengi dengan inisiasi edukasi lingkungan oleh pemerintah daerah.

\section{DAFTAR PUSTAKA}

Azmi, Z. 2008. Faktor-faktor yang mempengaruhi keputusan petani mengikuti program pengelolaan hutan bersama masyarakat serta pengaruhnya 
terhadap pendapatan dan curahan kerja (Studi kasus Desa Babakan, Kecamatan Tenjo, Kabupaten Bogor). Skripsi Program Studi Ekonomi Pertanan dan Sumber Daya, Faktultas Pertanian Bogor

Bailey, K. Methods of Social Research. New York: The Free Press

Contreras-Hermosilla, A. \& Fay, C. (2006). Memperkokoh pengelolaan hutan Indonesia: melalui pembaruan penguasaan tanah, permasalahan dan kerangka tindakan. Bogor: Bogor World Agroforestry Center dan Forest Trends.

Cramb, R. 1989. The use and productivity of labor in shifting cultivation: An East Malaysian case study. Agricultural Systems, 29 (2): 97-115.

Dove, M.R. 1983. Theories of swidden agriculture and the Political Economy of Ignorance. Agroforestry Systems, 1 (2): 85-89.

Damayanti, L. 2012. Pengaruh irigasi terhadap kesempatan kerja, kemiskinan dan ketahanan pangan rumahtangga tani di daerah irigasi Parigi Moutong. Disertasi Pasca UGM.

Fay, C dan G, Michon, 2005. Redressing forestry hegemony: When a forestry regulatory framework is best replaced by an agrarian and forest. Tree and liveliboods. Vol 15

Banham, Eleanor Kingwell and Fuller, Dorian Q. Shifting cultivation in South Asia: Expansion, marginalisation and specialization over the long term. Quaternary International, 249 (2012) 84-95.

Gujarati, D. 1991. Ekonometrika Dasar. Cet. II. Jakarta: Erlangga

Isdijoso, S.H., E. Sutisna and A. Bilang, 1990. Kajian aspek sosial ekonomi dalam rangka pengembangan kapas di lahan sawah bero. Penelitian Tanaman Tembakau dan Serat, Malang.

Mahdi dan Yonariza. What is the Minimum Rubber Price to Stop Farmers Converting Old Growth Forest into Shifting Cultivation ?. Malays. Appl. Biol. (2017) 46 (4): 111-118

Mertz, Ole et.al 2009. Swidden Change in Southeast Asia: Understanding Causes and Consequences. Human Ecology. 37, 259-264

Mertz,Ole., Tongmanivong, Sithong., Heinimann A., Phanvilay, K. Shifting Cultivation Stability and change: contrasting pathways of land use and livelihood change in Laos. Applied Geography, Vol. 46, 2014, p. 1-10

Mukul, Sharif A, Herbohn, 2016, The Impacts of shifting cultivation on secondary forests dynamics in tropics: A synthesis of the key findings and spatio temporal distribution of research, Enviromental Science \& Policy, 55 (2016) 167-77

Mulyoutami, Elok., Noordwijk, Meine Van., Sukantaladewi., Niken., Agus, Fahmuddin, 2010. Perubahan Pola Perladangan, Bogor: ICRAF.

Nugraha, Iman Sastra., Alamsyah, Aprial., Sahuri Sahuri., Komiditi Gambir sebagai Tanaman Sela diantara Karet untuk Meningkatkan Pendapatan Petani Karet (Studi Kasus: Desa Toman, Sumatera Selatan), E-Jurnal Warta Perkaretan Pusat Penelitian Karet, E-ISSN; 2503-5207, P-ISSN: 02 16-6062, Vol. 37, No 2 (2018) http:// ejurnal puslitkaret.co.id/index.php/wartakaret) 
Padoch, C. \& Pinedo-Vasquez, 2010. Saving Slash and Burn to save Biodiversity. Biotropica, 42 (5): 550-552.

$\mathrm{R}$ Lal, Shiftin cultivation verses Sustai-nable Intensification. Reference Module in Earth System and Enviromental Sciences, 2015

Raintree and Warner, 1986, Agroforestry pathways for the intensification of shifting cultivation, Agroforestry system, 4: 39-54

Rianto, Slamet, Strategi Petani Karet dalam Memenuhi Kebutuhan Hidup di Nagari Taruang-Tarung Kec. Rao Kabupaten Pasaman, Jurnal Spasial ISSN:2540, ISSN: 25414380, Program Studi Pendidikan Geografi STKIP PGRI Sumatera Barat, Vol 1, No 1 (2014)

Suratiyah, K. 2006. Ilmu Usahatani. Jakarta: Penebar Swadaya

Soekartawi, 1993. Prinsip dasar ekonomi pertanian teori dan aplikasi. Edisi Revisi. Jakarta: Rajawali Press.

Teegalapalli, Karthik and Datta, Aparajita, Field to a forest: Patterns of forest recovery following shifting cultivation in the Eastern Himalaya. Forest Ecology and Management. 364.173-182.10.1016/J. Foreco. 2016.01.006.

Van Vliet, N., Mertz, O., Heinimann, A., Laganke, T. \& Pascual,U. 2012. Trends, drivers, and impacts of changes in shifting cultivation in tropical forestagriculture frontiers: A global assessment. Global Environmeltal Change, 22 (2): 418-429.

Vongvisouk, T., Mertz, O., Thongmanivong, S., Heinimann, A. \& Phanvilay, K. 2014. Shifting cultivation stability and change: Constrasting pathways of land use and livelihood change in Laos. Applied Geography, 46: 1-10.

Wangpakapattawong, P., Kavinchan, N., Vaidhayakarn, C., Schmidt-Vogt, D. \& Elliot, S. 2010. Follow to Forest: Applying Indigenous and Scientific Knowledge of Shifting Cultivation to Tropical Forest Restoration. Forest Ecology and Management, 260 (8): 1399-1406.

Weriantoni., Srivani, Musbatik, Lukman., Fini, Febriani, Silvia dan Maivira, Analisis Faktor-faktor yang Mempengaruhi Kesejahteraan Petani Karet (Studi kasus di Nagari Limo Koto Kec. VII Kabupaten Sijunjung), Jurnal Teknologi Pertanian Andalas Vol. 21, No. 2, September 2017, ISSN 14010-1920, EISSN 25794019. 